\title{
WILLINGNESS TO PAY FOR URBAN WATER BODY RECREATIONAL FACILITIES: A CASE STUDY AT DIYATHA UYANA
}

\author{
Ratnayake,R, Wickramaarachchi, N, Wattage, P \\ University of Moratuwa, Katubedda, Sri Lanka \\ rangajeewar@gmail.com
}

\begin{abstract}
Revitalization of open water bodies into recreational areas are becoming widely popular in many parts of Sri Lanka. Understanding community perception and expectation on recreational development have important policy and cost-effectiveness implications. This paper explores the public perspectives on development, conservation and value of the open water recreational development at Diyatha Uyana and surrounding area. Contingent Valuation Method has been applied to estimate peoples' Willingness To Pay for recreational spaces in the selected area. A total of 300 residents from different socioeconomic backgrounds were selected randomly for the study. Enjoying peace and relaxation, taking children to play and breath clean air were mentioned as most important aspects of open water body areas. More frequent visits occur to enjoy peace and relaxation, breath clean air and enjoy the natural landscape. Almost all the participants were agreed upon conserving open water body areas in urban settings. Willingness to pay was significantly associated with income and occupation status. It yielded a monthly average payment of Rs.446.93 per household for another five years' time. The limited budget was the main reason for not willing to pay. This paper is significant as there is no contingent valuation method study has been carried on water body development in Sri Lanka.

Keywords: Contingent Valuation Method, Open water body development, Valuation of Ecosystem, Willingness to pay
\end{abstract}

\subsection{INTRODUCTION}

Demand for urban ecosystem services is growing everywhere in the world. Rapid urbanization and change of lifestyles require more public open spaces in cities to fulfil different socio, economic and environmental needs of the city population (Wolch, Byme, \& Newell, 2014). Public open spaces provide residents with outdoor recreational activities, contact with nature and enhance the biodiversity in the urban landscape. Ample urban open spaces indicate the livability and the sustainability of the modern cities (Chieura, 2004; Jim \& Chen, 2006). In recent years, open water body development and revitalizing have become a popular feature in the urban fabric of Sri Lanka. Properly designed and managed open water body area can facilitate engagement in the neighbourhood and the environment. Planning of open spaces, therefore need careful consideration of needs and aspirations of people.

Hence acknowledging the importance of public perceptions, planning bodies pay more attention to facilitate designer's perspectives. Further in the legal and planning process in Sri Lanka, public participation is not effectively considered. In order to create effective and sustainable open spaces, it is important to understand perceptions of local people on the development, conservation and their values. The concept of ecosystem services can be used to highlight the importance of preserving and sustainable management of open resources, hence attract the attention of relevant authorities to manage problems in a more efficient and effective manner and implement better policies (Nielsen, Olsen, \& Lundhede, 2007). Valuation of ecosystem services by attaching a monitory value to such services is more effective means of highlighting the importance of these natural resources which are being neglected otherwise 
(Hanemann, 1994).

This study used stated preference approach to assess the willingness to pay (WTP) of users and local people for recently revitalized open water body in Sri Jayawardenarapura Kotte Sri Lanka (political capital of Sri Lanka). The stated preference approach is an economic technique to estimate the monetary value of non-economic goods such as greenery, water bodies, and parks. In this family of research approach, Contingent Valuation Method (CVM) has been increasingly used in valuing environmental goods (Lo \& Jim, 2010). Even though more economically valuable natural resources lie in the developing countries, relatively few economic valuation studies have been carried out in this part of the world (Hadker, Sharma, David, \& Muraleedharan, 1997a). To the best of our knowledge, no CVM study has been carried on water body recreational development in Sri Lanka. This study is significant as the first study used the CVM to estimate the economic value of the open water body recreational area in Sri Lanka.

This paper organized as follows: section 2 provides a brief literature review of studies that used CVM to access WTP for urban ecosystem facilities. The next section discusses the study location and the research method. The design of the questionnaire is presented in detail in the second section. Results of 300 surveyed questionnaires are organized into four subsections: response rate and socioeconomic characteristics of respondents, importance and challenges of using urban water bodies, conservation of open water bodies and WTP. Next section summarises the study findings and develops the discussion. The conclusion of the paper discusses the applicability of economic valuation methods to value non-market goods in developing countries and future prospects in estimating economic value in environmental goods.

\subsection{LITERATURE REVIEW}

Providing high quality urban green spaces have become a key component of urban planning. Rapid urbanization, the rise of income level, changes of lifestyles and concerns on healthy living has increased the demand for urban open space recreational facilities (Berg et al., 2015). Therefore, many studies have emphasized the importance of accessing the monetary value of intangible and non-market benefits of open urban green spaces (Jim \& Chen, 2006).

Studies assessing the economic value of natural resources such as ecosystem services, biodiversity and wildlife, cultural goods and waste and resource management have increased with the increased awareness of aesthetic, ecological and environmental and public social functions of these resources (Choi, Ritchie, Papandrea, \& Bennett, 2010; Nielsen, Olsen, \& Lundhede, 2007; Noonan, 2003; Shang, Che, Yang, \& Jiang, 2012; Venkatachalam, 2004). In the past, aesthetic or scenic quality of environmental assets was valued using qualitative methods. Qualitative valuation of the environment is difficult to integrate into the assessment procedure (Tyrvainen \& Vaananen, 1998). Such methods have the limitation to provide a universal language to justify the importance of revitalizing and conserving non-market goods.

To address this limitation and to make the planning process systematic, some researchers have suggested applying environmental economic approaches to measure the market value of public goods. By adopting a monetary value to non-market goods provides a standard platform to compare and justify the rationale behind the policy decisions (Jim \& Chen, 2006)). Under this approach, CVM has been highlighted as a better way to determine whether the projects are in 
public interest and whether they need to be continued. The proper cost-benefit analyses can serve as the foundation for planning decisions and investment (Lindsey \& Knaap, 1999). Several government agencies have commissioned procedures for using CVM in their regulations. In this backdrop, the importance of assessing the economic value of non-market goods have been increasingly used in many countries (Hadker et al., 1997b; Lindsey \& Knaap, 1999, Tyrvainen \& Vaananen, 1998)

This literature review has briefly looked at the contingent valuation studies focusing on urban greenery recreational amenities. Mostly, these studies were focused to estimate the economic value of national parks (Bateman \& Langford, 1997; Hadker, Sharma, David, \& Muraleedharan, 1997b). Estimating non-market benefits of an urban park in Spain, Salazar and Melendez (2007) reported that the mean WTP is considerably higher for people who live closer to the parks. A study from China revealed that the income has a significant association with the WTP (Jim \& Chen, 2006). Lo and Jim (2010) reported that Hong Kong residents' willing to pay for urban green spaces is significantly associated with age and income. A study from India revealed that despite being a developing country with medium to low-income the participants are WTP to preserve environment amenities (Hadker, Sharma, David, \& Muraleedharan, 1997).

It was difficult to find any study conducted to assess the monetary value of open water body development and revitalizing a project. However, assessing the monetary value of water body recreational amenities, help the policymakers and planners to understand public views and also the sustainability of the project. In Sri Lanka, it is very rare to find CVM to solicit monetary values of open water bodies may be due to the lack of concern on using public views in the decision-making process. However, it is worthwhile to gauge information on public perceptions and expectations and also about the monetary value on the emerging trend of developing and revitalizing open water bodies Sri Lanka, because then the planners and policymakers can analyse the demand of people and justify the expenditure. Contingent valuation study on Diyatha Uyana and surroundings are of interest to many people because it is one of the widely used urban water body recreational areas in Sri Lanka.

\subsection{STUDY AREA AND METHODS}

\subsection{STUDY LOCATION- SRI JAYEWARDENEPURA KOTTE}

Sri Jayewardenepura Kotte is the legislative capital of Sri Lanka, located 8km southeast to the commercial capital of Colombo. During the $15^{\text {th }}$ to $16^{\text {th }}$ centuary, this area used to be the country's kingdom and called as Kotte. Currently, a municipality governs Sri Jayewardenepura Kotte and has developed into an urban area featuring a number of urban characteristics. Sri Jayewardenepura Kotte is a planned city with a number of government building including the Parliament of Sri Lanka and ministerial buildings. Despite the urban development the area still contains lagoons, swamps marshy lands and paddy fields.

In terms of the demographic characteristics, Sri Jayewardenepura Kotte municipality has a population of 107,925 living in an area of $17 \mathrm{~km} 2$. Age distribution of the population shows $70.3 \%$ of the population is in $15-64$ years age group while $18.3 \%$ in $0-14$ year age group and $11.4 \%$ of the population over 65 of years. 
The research site of Diyatha Uyana and surrounding areas are situated in Sri Jayewardenepura Kotte (see Map 1). It was established in 2012 under the guidance and close supervision of Urban Development Authority and the Secretary of Defense. The area sits between the Parliament complex and the Diyawannawa Oya. The marshy land on the banks of Diyawannawa Oya has been converted into parks with walking tracks, children's play areas, restaurants and small shops.

Map 1

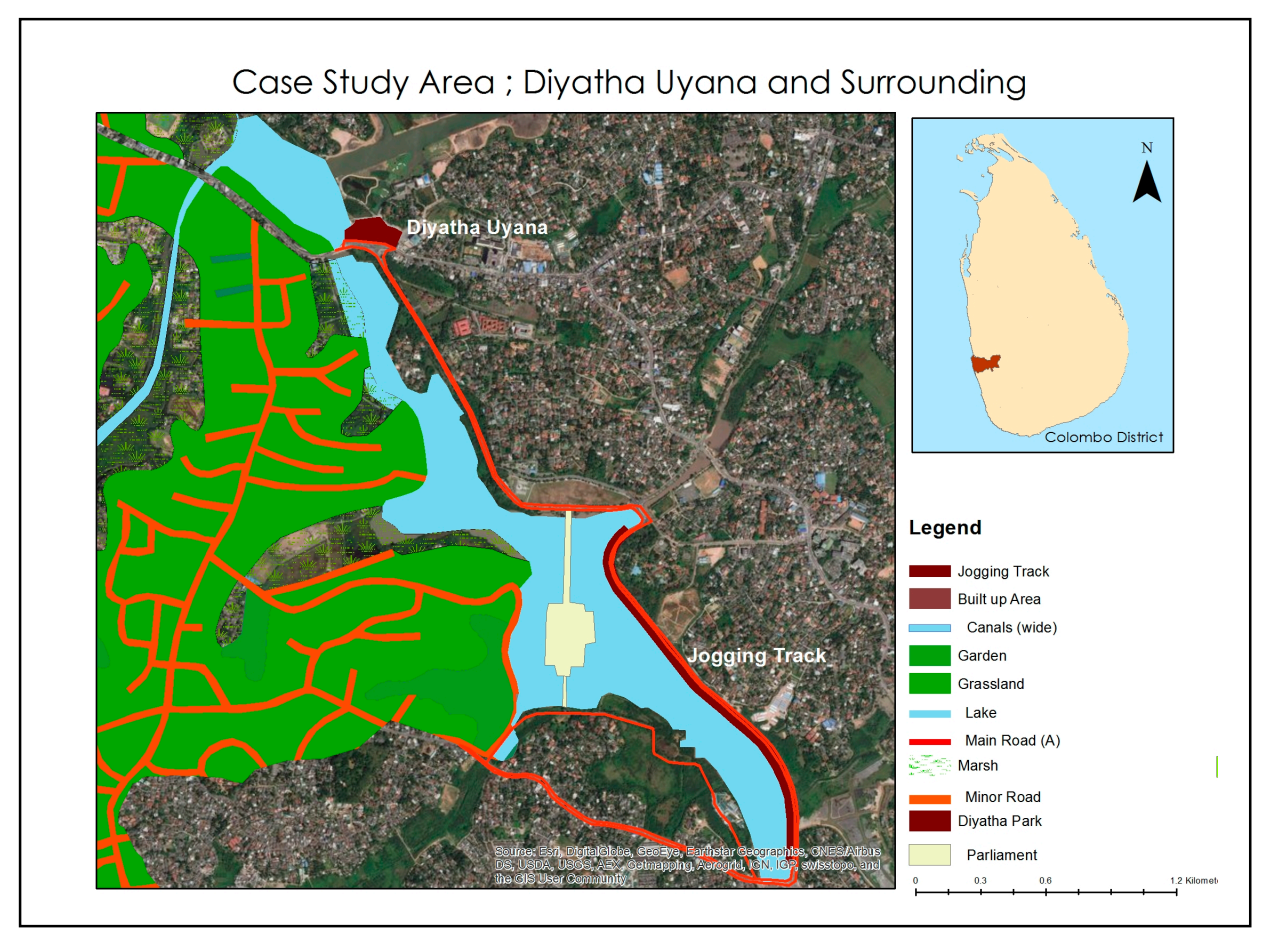

Source: Survey Department, Colombo, Sri Lanka, 2010.

\subsection{SAMPLING METHOD AND DATA ANALYSIS}

A total of three hundred people were adopted for the survey. The stratified sampling method was employed to ensure to capture different groups of people. Ten university students were recruited to conduct the survey in August 2017 on Sunday morning and afternoon. A survey was carried out on the site and also at neighbourhood houses. The data were analyzed using SPSS software. Linear regression models were constructed to identify the factors associated with the stated WTP.

\subsection{QUESTIONNAIRE DESIGN}

The current research used CVM to estimate WTP for preservation and management of the open water body recreational area in Diayatha Uyana and surrounding area. It was a questionnairebased approach to assess the economic value of non-market goods. CVM provides three different formats when eliciting monetary value: Dichotomous choice, open-ended, and payment card approaches (Venkatachalam, 2004). Previously, both dichotomous choice and open-ended 
payment card approaches have been commonly used in assessing the economic value (Lo \& Jim, 2010). However, both methods faced practical limitations. The dichotomous method seeks participants' willingness or not willingness to pay for a given amount by researchers. Even though this question is easy to understand for the participants it requires a large sample size and also it restricts having an actual preferred value of the respondents. The open-ended method provides the better variation of participants' preferred value it requires participants' understanding of bidding system. Payment card approach has been emerged as a hybrid of these two approaches and has been adopted in recent studies (Jim \& Chen, 2006).

The current study used payment card approach. The dichotomous approach was less applicable with the resource constraints. The open-ended question method is hard to practice with the citizens of Sri Lanka as most Sri Lankan are not familiar with assigning a monetary value to non-market commodities. To overcome these limitations, payment card approach was adopted which provides participants with a direct prompt and also provide the space for respondents to indicate their preferred amount if they are not satisfied with the given choice.

The design of the questionnaire is important in contingent valuation studies (Tyrvainen \& Vaananen, 1998). The questionnaire starts with a brief introduction explaining the aims of the survey. The first section of the questionnaire explored the respondents' level of participation in different activities at Diyatha Uyana and the surrounding area. First, eight groups of questions seek the importance of open water body for the users and non-users in different activities. Next question recorded the frequency of participation in the above eight activities. Final question under the section one explored the challenges when using the open water body.

Section two explored respondents' perceptions of conserving open water bodies. The first question asked whether conservation is important for the users and non-users. Next two sets of debriefing questions were used depending on the response to question 4 (Do you think the conservation of open water body is important to you?). If the answer was yes, they have presented a scaling question with eleven statements to rank the importance of conservation open water bodies. The negative respondents were presented a scaling question nine statement to rank the negative effects of conserving open water bodies.

The WTP questions started with a hypothetical statement mentioning the reduction of public open spaces in the Sri Jayewardenepura Municipal council area. Further it explained the social and environmental problems that can arise from the reduction of open spaces in urban areas. Respondents were recommended to consider their financial circumstances, habits and preferences and the environmental features of the area. before filling these questions. The respondents were asked to state their willingness to pay for conservation and development of open water body of a given amount (Rs.1000.00 per month). This amount was selected as an equal average amount of normal monthly fee for a Gymnasium in this area. Then an open-ended question was asked the participants to bid their payment.

After stating their WTP, positive bidders were presented open-ended question to know the motives of their action. Non-positive bidders (Rs 00) were presented another open-ended question to see the rationale behind choosing not to pay for the open water body revitalizing the program. 
The questionnaire ends with 12 questions gleaning respondents' socio-economic characteristics. Such data helped to assertion whether socio-economic status affects willingness to pay.

\subsection{RESULTS}

\subsection{RESPONSE RATE AND SOCIOECONOMIC CHARACTERISTICS OF RESPONDENTS}

A total number of 300 questionnaires were filled by face to face interviews or by the respondents themselves. Socio-economic profile shows that over half of the respondents $(62.0 \%)$ were in 30 49 of age group (Table 1). Fifty-seven percent of respondents have completed their high school education and forty percent have obtained a university or higher degrees. In terms of monthly income, nearly half of the respondents fall within Rs. 50,000- 100,000 monthly household income bracket. Fewer respondents indicated over Rs. 300,000 income level. Over one-quarter of participants $(27.0 \%)$ reported $<$ Rs. 50,000 household income. Over three-quarters of the respondents indicated they are employed full-time or part-time basis.

Table 1

\begin{tabular}{lll}
\hline Socio-economic variables & Categories & Survey \% \\
\hline Age & $<30$ years & 21.3 \\
& $30-49$ years & 62.0 \\
& $>50$ & 16.7 \\
\hline Monthly household income & $<$ Rs. 30,000 & 6.0 \\
& Rs.30,000- 49,000 & 21.3 \\
& Rs.50,000-100,000 & 48.3 \\
& Rs. 100,000-300,000 & 22.0 \\
& Rs. $>300,000$ & 2.3 \\
\hline Education & Primary school & 2.3 \\
& High school & 57.3 \\
& University & 15.7 \\
& Post Graduate & 24.7 \\
\hline Gender & Male & 64.3 \\
& Female & 35.7 \\
\hline Employment & Full-Time & 72.3 \\
& Part Time & 6.3 \\
& Unemployed & 9.7 \\
& Studying & 9.7 \\
& Retired & 2.0 \\
\hline
\end{tabular}

\subsection{IMPORTANCE AND CHALLENGES OF USING URBAN WATER BODIES}

The survey gathered information on the importance of open water bodies, the frequency of uses and challenges facing by users and non-users. Visits to open water body are induced by different activities. The most important aspect of the open water body is to provide a peace and relaxed atmosphere (Table 2). Dwellers of Sri Jayewardenepura are now facing lack of open greenery spaces close to their houses. Therefore, open spaces like Diyatha Uyana and surroundings 
provide a calming characteristic to the environment. Taking children to play and breathe fresh air was another aspect ranked as important by the participants of the study. Again, the lack of open back garden areas in the neighbourhood and the busy lifestyle of parents limit children's activities. By taking children to open areas increases physical activities as well as social interaction skills of children. Physical exercise and stroll was ranked as the fourth important factor and provides a clear indication of the need for open spaces in high-density urban areas to support residents' physical well-being.

Table 2

Why might open water body be important to you?

\begin{tabular}{llllllll}
\hline Categories & \multicolumn{3}{l}{ Valid responses \% } & & & Score & Rank \\
\cline { 2 - 7 } & SD & D & N & A & SA & & \\
\hline Exercise or stroll & 6.3 & 1.3 & 9.3 & 37.7 & 45.3 & 343 & 4 \\
Breath clean air & 1.0 & 1,0 & 16.3 & 45.0 & 36.7 & 346 & 3 \\
Chat or gather with friends & 3.0 & 3.0 & 18.2 & 44.1 & 31.6 & 292 & 6 \\
Take children to play group & 4.4 & 0.7 & 10.1 & 33.9 & 51.0 & 377 & 2 \\
Biking & 44.3 & 11.1 & 18.9 & 14.5 & 11.1 & -186 & 9 \\
While away time & 7.4 & 4.7 & 22.8 & 43.0 & 22.1 & 202 & 8 \\
Enjoy the natural landscape & 2.7 & 4.7 & 19.0 & 40.0 & 33.7 & 292 & 5 \\
Add an economic value to the area & 6.7 & 9.4 & 18.1 & 35.2 & 30.5 & 219 & 7 \\
Enjoy the peace and relaxation & 0.0 & 1.0 & 7.4 & 33.8 & 57.9 & 444 & 1 \\
\hline
\end{tabular}

$\mathrm{SD}=$ Strongly Disagree, $\mathrm{D}=$ Disagree, $\mathrm{N}=$ Neutral, $\mathrm{A}=$ Agree, $\mathrm{SA}=$ Strongly Agree

Aggregate score is calculated by summing the weights given to $=\mathrm{SD}=-2, \mathrm{D}=-1, \mathrm{~N}=0, \mathrm{~A}=1, \mathrm{SA}=2$

Enjoy the natural landscape, chat or gather with friends and add an economic value to the area were ranked less important. While away from home was less important probably due to the busy lifestyle. This finding is compatible with Lo and Jim's (2010) study on Hong Kong urban greenery. Lastly, biking was least important. This may indicate the less accessibility of separate biking paths to reach the Diyatha Uyana and surrounding parks and also because of the business of the place.

Most frequent visits were occurred to enjoy the peace and relaxation, breath clean air and to enjoy the natural landscape (Table 3). This reflects the users and non-users desire for tranquility in the middle of the busy urban lifestyle.

Table 3

How often do you participate in the following activities?

\begin{tabular}{|c|c|c|c|c|c|c|}
\hline \multirow[t]{2}{*}{ Categories } & \multicolumn{4}{|c|}{ Valid responses \% } & \multirow[t]{2}{*}{ Score } & \multirow[t]{2}{*}{ Rank } \\
\hline & Never & Rarely & Sometimes & Often & & \\
\hline Exercise or stroll & 19.7 & 13.7 & 29.3 & 37.3 & 553 & 4 \\
\hline Breath clean air & 4.7 & 24.0 & 41.3 & 30.0 & 588 & 2 \\
\hline Chat or gather with friends & 9.7 & 27.4 & 45.5 & 17.1 & 507 & 6 \\
\hline Take children to play group & 21.7 & 12.7 & 29.7 & 35.7 & 537 & 5 \\
\hline Biking & 78.6 & 10 & 9 & 2 & 188 & 8 \\
\hline While away time & 16 & 24.3 & 42.3 & 17 & 480 & 7 \\
\hline
\end{tabular}


Enjoy the natural landscape

Enjoy the peace and relaxation
$9.3 \quad 18.3$

$4 \quad 10.3$
48.7

43.3
$23.3 \quad 557$

41.3663
3

1

Aggregate score is calculated by summing the weights given to $=$ Never $=0$, Rarely $=1$, Sometimes $=2$, Often $=3$,

The survey gauged information on challenges of using Diyatha Uyana and surrounding area. Inadequate parking and sporting facilities were the most mentioned difficulties facing the participants. The findings of this study can be useful in proposing open water body development in urban areas, as some (23\%) mentioned incapability of finding a park close to their residence. Apart from these difficulties, inadequate seating facilities and poor hygiene facilities were also mentioned as challenges in using the area.

Under the other category, around $38 \%$ of participants have mentioned maintenance issues as obstacles in using Diyatha Uyana. Fewer trees (27\%), poor sanitation facilities (19\%) and lack of shade $(7 \%)$ were the most mentioned issues under another category. Public concern about their safety has to take consideration as it was mentioned few times under the other category. Some people indicated their concern on gang behaviours, drug problems as a primary concern for their security.

\subsection{CONSERVATION OF OPEN WATER BODY}

The survey seeks respondents' attitudes towards conserving open water bodies in urban areas. Almost all the participants (99\%) agreed upon conserving open water body areas in their neighbourhood. The motivations behind their attitudes were gauged using eleven debriefing questions (Table 4). Place for relaxation or whiling away from home topped the list. This indicates that the people seek more places to relax in the midst of their busy lifestyles. Many respondents were encouraged to save open areas thinking about environmental benefits.

Table 4

Importance of conservation

\begin{tabular}{|c|c|c|c|c|c|c|c|}
\hline \multirow[t]{2}{*}{ Category } & \multicolumn{5}{|c|}{ Valid Responses } & \multirow[t]{2}{*}{ Score } & \multirow[t]{2}{*}{ Rank } \\
\hline & $\begin{array}{l}\text { Not at } \\
\text { all }\end{array}$ & $\begin{array}{l}\text { Sligh } \\
\text { tly }\end{array}$ & $\begin{array}{l}\text { Somewh } \\
\text { at }\end{array}$ & Very & Extremely & & \\
\hline $\begin{array}{l}\text { Encourage } \\
\text { activities }\end{array}$ & 2.0 & 0.7 & 9.4 & 42.3 & 45.0 & 972 & 2 \\
\hline $\begin{array}{l}\text { Increase property value of } \\
\text { the area }\end{array}$ & 3.0 & 4.9 & 16.8 & 45.5 & 29.1 & 781 & 10 \\
\hline Enhance aesthetic quality & 2.7 & 5.3 & 11.7 & 40.7 & 38,3 & 912 & 5 \\
\hline Present wild life habitat & 15.3 & 19.0 & 21.7 & 22.0 & 20.7 & 633 & 11 \\
\hline Good for public health & 3.0 & 10.7 & 14.7 & 45.3 & 25.3 & 832 & 9 \\
\hline $\begin{array}{l}\text { Strengthen community } \\
\text { sprit }\end{array}$ & 0.7 & 3.3 & 14.3 & 46.0 & 34.3 & 922 & 4 \\
\hline
\end{tabular}




\begin{tabular}{llllllll} 
Reduce air pollution & 3.3 & 8.0 & 18.3 & 39.3 & 29.7 & 844 & 8 \\
$\begin{array}{l}\text { Purify air and } \\
\text { environment }\end{array}$ & 0.7 & 8.3 & 16.3 & 39.0 & 34.3 & 886 & 7 \\
$\begin{array}{l}\text { Cools the atmosphere } \\
\begin{array}{l}\text { Allow more contact with } \\
\text { nature }\end{array}\end{array}$ & 2.0 & 7.7 & 13.0 & 41.0 & 35.0 & 890 & 6 \\
$\begin{array}{l}\text { Place for relaxing or } \\
\text { whiling away from home }\end{array}$ & 0.3 & 3.0 & 7.0 & 4.0 & 54.7 & 1013 & 1 \\
\hline
\end{tabular}

Average scores $=-0=$ Not at all, $1=$ Slightly, $2=$ Somewhat, $3=$ Very, $4=$ Extremely Important

\subsection{WILLINGNESS TO PAY}

The survey question 7 was targeted to gauge household's WTP to support the development of urban water body and conservation program. First people were asked whether they are willing to pay for a given amount (Rs.1000.00) monthly. About 67 percent $(n=201)$ of respondents showed their support for the program by saying they are WTP a price. There was 33 percent of $(n=99)$ zero bids. Next, asked them to indicate their perceived amount of payment. The mean WTP of households was Rs.446.93 monthly and which will amount Rs. 5,363.16 per year, suggesting that people are willing to pay a notable amount of money to develop and conserve open water bodies.

Multiple linear regression model was applied to estimate factor affecting for respondent's WTP (Table 5). All the respondents who did not answer were removed before running the program.

\section{Table 5}

Linear regression model for the respondent's willingness to pay for development and conserve of urban water bodies.

\begin{tabular}{|c|c|c|c|c|c|}
\hline \multicolumn{6}{|c|}{ Coefficients $^{a}$} \\
\hline \multirow[b]{2}{*}{ Model } & \multicolumn{2}{|c|}{ Unstandardized Coefficients } & $\begin{array}{l}\text { Standardized } \\
\text { Coefficients }\end{array}$ & $t$ & Sig. \\
\hline & $\beta$ & Std. Error & $B$ & & \\
\hline 1 Constant & -2760.915 & 1022.412 & & -2.700 & .008 \\
\hline Income & 244.858 & 78.926 & .239 & 3.102 & .002 \\
\hline Age & 23.024 & 233.569 & .008 & .099 & .922 \\
\hline $\begin{array}{l}\text { Environmental } \\
\text { Group }\end{array}$ & 66.832 & 76.040 & .065 & 879 & .381 \\
\hline$J o b$ & 184.061 & 68.509 & .199 & 2.687 & .008 \\
\hline Gender & 257.977 & 121.875 & .162 & 2.117 & .036 \\
\hline
\end{tabular}

a. Dependent Variable: WTPMXAMT 
As indicated in $F$ test (or global test), the entire model is highly significant at $\alpha=0.01$ (or $1 \%$ ) level. Among the other independent variables Income and job are significant at $\alpha=0.01$ level. The gender variable is also significant at $\alpha=0.05$ level. For every one-unit change in gender, the $\log$ odds of admission (versus non-admission) increases by 0.002 .The expected sign for all independent variables chosen are positively contribute towards the WTP values. Variables of age and being a member of an environment group are however not significant.

\subsection{DISCUSSION}

The survey results suggest people's strong desire in developing and conserving open water bodies in urban areas. This finding can be used to justify the planning decisions and also expenditure used upon developing urban water body recreational areas in cities.

The importance (Table 2) and the occurrence of visiting (Table 3) open water bodies showed an overlapping ranking indicating people's high desire for having an attachment to the natural environment. The three top ranks for visiting open water bodies were related to acquiring environmental benefits. This may due to the reduction of open places in Sri Jayewardenepura municipal area with the fast urbanisation. With the busy lifestyle and the reduction of open spaces in a neighbourhood may have restricted the attachment with nature and the community and open water bodies have started to re-generate this behaviour. This behaviour pattern is somewhat related to the western people's motivations of visiting open green spaces. However, this is different from the findings from Hong-Kong (Jim \& Chen, 2006). The changes of Sri Jayewardene Pura land use show the reduction of water bodies and marshy land. According to 2010 data of land use patterns show that this area consists $10.4 \%$ marshy land and $2.1 \%$ lakes which are very sensitive to eco-diversity. The survey results in emphasis the need for developing and conserving open spaces in urban areas.

No parking places is a common issue facing the users of urban facilities such as open recreational areas. The increase of car ownership and peaceful environment after the civil war has accelerated people's mobility. The increase of public transportation would reduce the pressure on providing parking spaces. Lack of availability of open spaces seems to be an issue for the participants of the survey. This suggests the need for upgrading public open spaces in urban areas. There can be neighbourhood small potential places which have been neglected because of the more attractive urban recreational areas. Localizing some open recreational areas in neighbourhoods will reduce the pressure on city level places like Diyatha Uyana. Future urban recreational planning can use landscape ecological approach to maximize the spatial, social and environmental benefits (Jim \& Chen, 2006).

Overall, lack of infrastructure facilities was mentioned as obstacles in using Diyatha Uyana and surrounding recreational area. A requirement of more sporting facilities indicates people's increasing consciousness on health and wellbeing. This reflects the answers given to question one (Table 2) and two (Table 3). Respondents ranked exercise and stroll at the fourth most important function and also as the fourth in visiting order. With the busy and unhealthy lifestyle urban dwellers are now becoming more aware of the need for physical activities.

\subsection{WILLINGNESS TO PAY TO USE OPEN WATER BODY}


The findings of this study show the WTP for open water body recreational areas is high among the users and non-users of this study. It is significant for a developing country with people who have limited experience in applying a monetary value to eco-service systems. Currently, there is no entrance fee for open water body recreational areas in the country. Therefore, this research indicates that even people use these facilities for free for years in-return they have a moral feeling to pay for eco-service systems. The mean value of this study is half of the amount usually people pay monthly for an indoor physical exercise centre in Sri Lanka.

This study found that only income had a significant positive influence on willingness to pay. This is more compatible with some studies around the world regardless of the economic development of the country (Jim \& Chen, 2006). This indicates that still Sri Lankan people consider recreational and amenity enjoyment as a superior good. The findings revealed that the moral and ethical considerations are not considered in valuing environmental amenities by the participants of this study. In general, it connotes that those who have high income can afford for other services than their basic needs. On the other hand, it indicates that people who can have lower income could exclude from using environmental amenities if an entrance fee was introduced. This should be given more consideration when making policy decisions in future regarding enforcing fees to use natural resources. However, Tyrvainen and Vaanane's (1998) study on the urban forest in Finland revealed that the income does not have any significant impact on people's willingness to pay. This study shows the positive attitudes of people's moral and ethical consideration of the environment. This is a promising indication of protecting ecological systems, and to stop pollution in the country.

\subsection{CONCLUSION}

Sir Lankans have little experience of conducting CV surveys. This needs to be considered when analyzing the data from the current study. The idea of applying a monetary value for the environmental good seems to be unusual for some participants. As a new concept, it took time for the participant to understand the hypothetical situation. Some people might have thought of an actual payment and could have given a lower amount regardless of their actual willingness. Therefore, careful consideration should be given in drafting the survey and should give special emphasis to highlight the hypothetical situation in the survey.

Adopting a monetary value for eco-service systems could provide a justification for policy makers and planners. Development plans can be incorporated into public views and monetary value. By understanding people's motivation and incorporating them into planning decisions in return would attract more support in maintaining and conserving rather neglecting eco-service systems, thinking or criticizing them as a government project.

Finally, the current study provides a green light in conducting more CV studies for valuing not only water body recreational developments in the country but also for the other environmental goods such as forests, biodiversity, eco-tourism and water resources. More and more economic valuations on urban open spaces would influence the policy and planning decision in the country. Therefore, it is important to conduct this kind of studies and then the people also would use to adopting an economic value for the environmental goods. 


\section{References}

Bateman, I. J., \& Langford, I. H. 1997, Non-users' willingness to pay for National Park: An application and critique of the contingent valuation method. Regional Studies, 31(6), 571.

Berg, M.V. D., Wendel-Vos, W., Proppel, M., Kemper, H., Mechelen, W. V., \& Maas, J. 2015, Health benefits of green spaces in the living environment: A systematic review of epidemiological studies. Urban Forestry \& Urban Greening, 14(4), 806-816.

Breffle, W. S., Morey, E. R., \& Lodder, T. S. 1998, Using contingent valuation to estimate a neighbourhood's willingness to pay to preserve undeveloped urban land. Urban Studies, 35(4), 715-727.

Chieura, A. (2004). The role of urban parks for the sustainable city. Landscape and Urban Planning, 68(1), 129-138.

Choi, A. S., Ritchie, B. W., Papandrea, F., \& Bennett, J. 2010, Economic valuation of cultural heritage sites: A choice modelling approach. Tourism Management, 31, 213-220.

Hadker, N., Sharma, S., David, A., \& Muraleedharan, T. R. 1997, Willingness-to-pay for Borivli National Park: Evidence from a Contingent Valuation. Ecological Economics, 27, 105-127.

Hanemann, W. M. 1994, Valuing the environment through contingent valuation. The Journal of Economic

Perspectives, 8(4), 19-43.

Jim, C. Y., \& Chen, W. Y. 2006, Recreation-amenity use and contingent valuation of urban green spaces in Guangzhou,

China. Landscape and Urban Planning, 75, 81-96.

Lindsey, G., \& Knaap, G. 1999, Willingness to pay for urban greenway projects. Journal of American Planning Association, 65(3), 297-354.

Lo, A. Y., \& Jim, C. Y. 2010, Willingness of residents to pay and motives for conservation of urban green spaces in the compact city of Hong Kong. Urban Forestry \& Urban Greening, 113-120.

Noonan, D. 2003, Contingent valuation and cultural resources: A meta-analytic review of the literature. Journal of Cultural Economics, 27, 159-176.

Nielsen, A. B., Olsen, S. B., \& Lundhede, T. 2007, An economic valuation of the recreational benefits associated with nature-based forest management practices. Landscape and Urban Planning, 80, 63-71.

Rahim, K. A. 2008, Contingent Valuation Method. Paper presented at the Regional Training Workshop: Economic

Valuation of the Goods and Services of Coastal Habitats, Thailand

Ratnayake, R., Silva, C., Warusawitharana, E. (2017). An examination of the temporal effects of environmental cues on pedestrians' feelings of safety. Computers Environment and Urban Systems, 64, $266-274$.

Ratnayake, R. (2017). Sense of safety in public spaces: university students' safety experiences in an Australian regional city, Rural Society, 26(1), 69-84.

Ratnayake,R., Butt, A. (2017). Encounters with unfamiliar: International planning education. International Planning Studies, DOI10.1080/13563475.2017.1339347

Ratnayake, R. (2013). Fear of crime in urban settings: Influence of environmental features, presence of people and social variables. Bhumi: The Planning Research Journal, 6(1), 25-38.

Ratnayake, R. (2006). Gender and planning in Sri Lanka. Bulit Enviornment, 25(3), 28-39.

Ratnayake, R., Butt, A., \& Budge, T. (2013). Planning education and inter-cultural collaboration: awareness, innovation, reflection and preparation for practice. Bhumi:The Planning Research Journal, 3(1), 10-19.

Ratnayake, R. (2013c). Fear of crime in urban settings: Influence of environmental features, presence of people and social variables. Bhumi: The Planning Research Journal, 3(2), 30-43.

Ranasinghe, G., Amarawickrama, S., Ratnayake, R., Randeniya, T., \& Rathnasiri, S. (2015). A model for assessing the level of walkability in urban neighbourhoods in Sri Lanka. International Journal of Built Environment and Sustainability, 2(4), 292-300.

Ratnayake, R. (2015). Small traditional retail shops vs super markets and emerging shopping malls in a Sri Lankan city. Bhumi: The Planning Research Journal, Special Issue, 44-57.

Ranasinghe, G., Amarawickrama, S., \& Ratnayake, R. (2016). A study to compare the level of walkability in two urban neighbourhoods of Sri Lanka. International Journal of Engineering Research and General ScienceBuilt, 4(1), 6-13. Salazar, S. d. S., \& Menendez, L. G. 2007, Estimating the non-market benefits of an urban park: Does proximity matter? Land Use Policy, 24, 296-305.

Shang, Z., Che, Y., Yang, K., \& Jiang, Y. 2012, Assessing Local Communities' Willingness to Pay for River Network Protection: A Contingent Valuation Study of Shanghai, China. International Journal of Environmental Research and Public Health, 9, 3867-3887.

Tyrvainen, L., \& Vaananen, H. 1998, The economic value of urban forest amenities: An application of the contingent valuation method. Landscape and Urban Planning, 43, 105-118. 
Venkatachalam, L. 2004, The contingent valuation method: A review. Environmental Impact Assessment Review, 24(1), 89-124.

Wolch, J. R., Byme, J., \& Newell, J. P. 2014, Urban green space, public health, and environmental justice: The challenge of making cities 'just green enough' . Landscape and Urban Planning, 125, 234-244. 